\title{
Memory \& Cognition: The first 40 years
}

\author{
Colin M. MacLeod ${ }^{1}$
}

Accepted: 19 September 2020 / Published online: 2 October 2020

(C) The Psychonomic Society, Inc. 2020

\begin{abstract}
This article presents a survey of the first 40 years of this journal, covering (1) the origin and subsequent history of the journal, (2) who the editors have been, (3) the influence of the journal and its editors on the field, and (4) the most frequently cited articles. A virtually immediate success, Memory \& Cognition has gone on to become one of the leading journals in the field of cognitive psychology.
\end{abstract}

Keywords History

My goal in this article is to present a portrait of the first 40 years of this journal, from 1973 through 2012. Memory \& Cognition has played an important role in the growth inand the increased influence of - cognitive psychology and the Psychonomic Society, so a look back is warranted, and will also provide some perspective on how the field has developed. Why choose 40 years? We are not yet ready for a $50-$ year review, and, given that one aspect of what I want to report (notable citations) only makes sense after the passage of some time, 40 years meets that constraint. I will describe how the journal began, sketch who the editors have been, consider how the journal and its editors have influenced the field, and summarize the most influential articles in the first 40 years.

\section{How the journal began}

The Psychonomic Society was established on December 31, 1959, its goal being "especially to provide an adequate forum for the presentation and discussion of psychological research" (Dewsbury \& Bolles, 1995, p. 216). The first annual meeting took place September 1-3, 1960, at the University of Chicago. Details of the Society's origin are provided by Dewsbury and Bolles in the first of a series of four historical articles. The three subsequent historical articles describe the journal publishing program (Dewsbury, 1996), the annual meetings of the

Colin M. MacLeod

cmacleod@uwaterloo.ca

1 Department of Psychology, University of Waterloo, Waterloo, Ontario N2L 3G1, Canada
Society (Dewsbury, 1997a), and the Society's development through the years (Dewsbury, 1997b).

From the earliest meetings about establishing such an organization, the issue of whether the Society should publish its own journals was front and center, as Dewsbury (1996) describes in admirable detail. Indeed, Dewsbury and Bolles (1995) append the original bylaws of the Society (formally adopted December 30, 1959), and it is noteworthy that Article VII (of 10) specifically addresses journal publications: "With approval of the membership, the Governing Board may undertake the editing, or publishing, or both, of scientific journals" (pp. 229-230).

Although journal publication did not happen right away, by 1964, the first Society journal—Psychonomic Science-appeared in print, having been created, according to Dewsbury (1996), "on his own" (p. 324) by Clifford T. Morgan. In 1966, Morgan decided that Psychonomic Science should split articles dealing with animal and physiological topics from those dealing with human experimental areas into separate sections of the journal, setting the stage for the development of more domain-specific journals. The first of these-Perception \& Psychophysics - appeared in 1966. By 1968, when Behavior Research Methods and Instrumentation debuted, Morgan already was suggesting that Psychonomic Science should be fractionated into multiple specialty journals. It took until 1971 for a committee to be created by the Governing Board to consider how the Society should proceed with respect to publications. That committee made five recommendations to the Board, the second of which was for the establishment of three new journals: Animal Learning and Behavior, Physiological Psychology, and Memory \& Cognition. All three were promptly instituted, with submissions for their initial volumes occurring during 1972. From their creation, these 


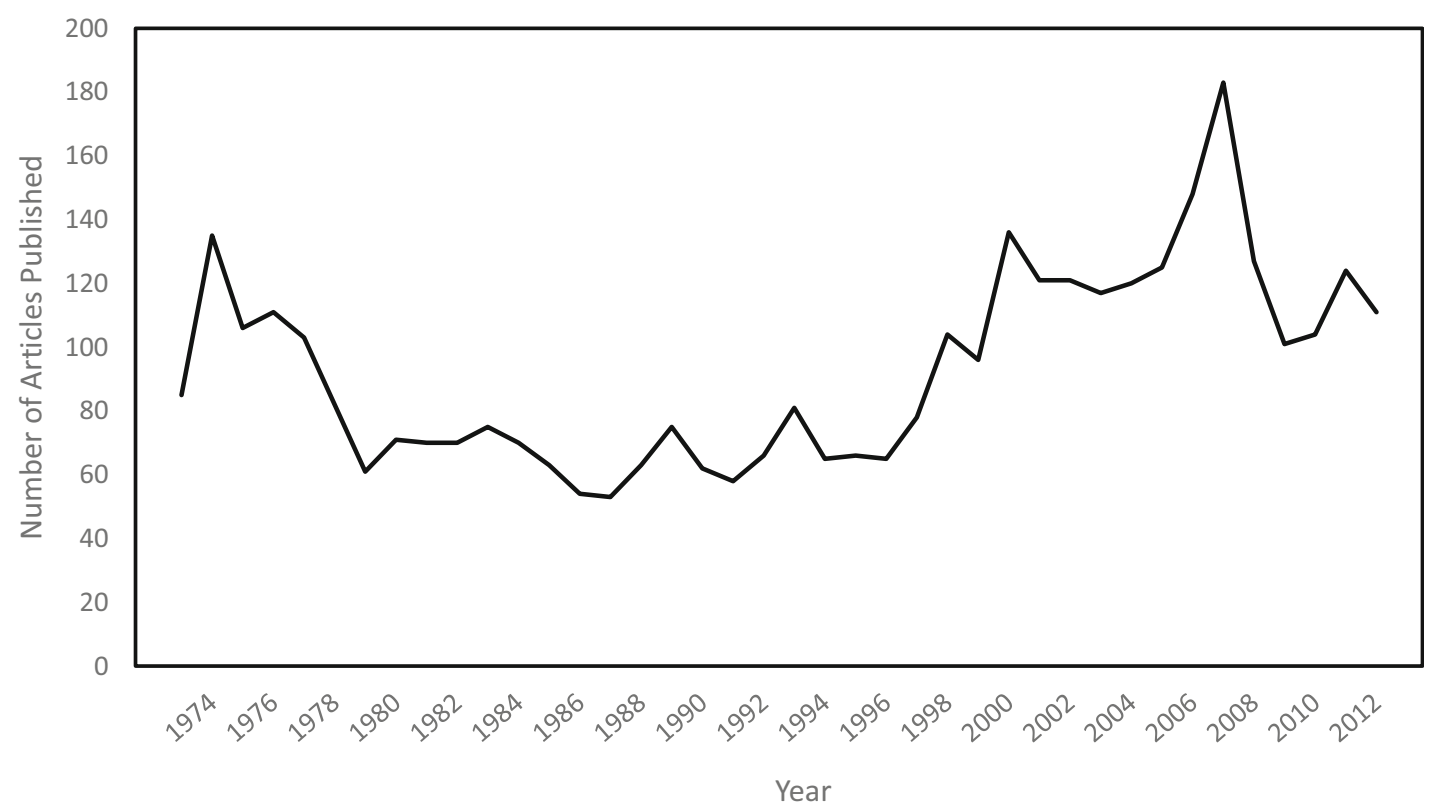

Fig. 1 Number of articles published in Memory \& Cognition for each of the 40 years 1973-2012

three journals all were fully refereed, unlike Psychonomic Science, which had been lightly edited.

In 1973, these three journals did in fact debut in print. Memory \& Cognition was initially published quarterly, with its first issue in January 1973. The inaugural editors were George E. Briggs and Rudolph W. Schulz, carrying on their work as editors of the Psychonomic Science Section on Human Experimental Psychology. In Psychonomic Science, Briggs had been responsible for perception, performance, and experimental social psychology and Schulz had been responsible for memory, learning, and thinking. The first article to appear in the inaugural issue of Memory \& Cognition, entitled "On the selection of signals," was by Posner, Klein, Summers, and Buggie (1973). Other noted experimental psychologists whose papers appeared in that first issue included Wendell Garner, Leo Postman, and Benton Underwood. The most cited article in the first volume was Dyer's (1973) review of the Stroop literature.

Over the years, apart from periodic changes in the cover design, the most notable changes were in the number of issues published annually, with increases responding to the success of the journal. This number increased twice - quickly from the original four to six issues in 1975 (Volume 3), where it remained for 25 years until 2000 (Volume 28), when it increased to eight issues, the current complement. Although the first 5 years saw from 85 to 135 articles published in each volume, the number of articles settled into the range of 60 to 80 annually from then until 1998, when the number rose again - with a few exceptions - to the current range of 100 120 annually. Figure 1 shows the number of articles published in each of the first 40 years. Records of submissions were available only for the years 2008-2012 (and thereafter).
Submissions increased quite monotonically from 473 in 2008 to 575 in 2012, with rejection rates annually in those five years hovering very close to $80 \%$ (range $77 \%-83 \%$ ). In their editorials two decades earlier, Healy (1986) mentioned a rejection rate of "between $70 \%$ and $80 \%$," and IntonsPeterson (1990) noted that "the acceptance rate is about $20 \%$," so this pattern seems to have been quite consistent through the years. ${ }^{1}$

\section{The editors}

In the first 40 years of the journal, there were 11 editors, beginning with a joint editorship and followed by a series of editors-in-chief who, with one exception, each served a 4-year term. As will become apparent, the diversity in the areas of primary expertise of the editors has been good for the journal, fostering diversity in the topics of the submissions. Put simply, Memory \& Cognition is aptly named.

The search for the next editor ordinarily begins around the time of the annual meeting of the Psychonomic Society in November, 14 months before the new editorial team will begin to receive manuscripts - and therefore 26 months before the names of the new editorial team appear on the cover of the journal. The search is conducted by a search committee whose chair is appointed by the

\footnotetext{
${ }^{1}$ What exactly is meant by "rejection rate" is not absolutely clear; the term is used in different ways. I assume that what is meant here is that, of all submissions, approximately $80 \%$ are rejected and only $20 \%$ are published. Of course, some of the submissions that are initially rejected may subsequently be extensively revised and may then cross the threshold for acceptance; including these in the calculation would result in a lower rejection rate.
} 
Publications Committee of the Society; the chair then fills out the search committee-typically three more members of the Society-with the approval of the Publications Committee. The search committee then solicits nominations and ultimately recommends one of the nominees to the Publications Committee for its approval.

Once the new editor is approved and has agreed to take on the position, usually by June (i.e., after about $6-8$ months required for the search process), the now editorelect begins the process of recruiting associate editors and members of the editorial board (the consulting editors).
This process is completed before January, which is when the new team replaces the previous team and begins processing manuscripts. The outgoing team's names remain on the cover for that calendar year because the articles being published in that year will almost all have been acted on by the outgoing team.

Table 1 lists the 11 editors, their affiliations, and their editorial terms; Fig. 2 presents photographs of each of them. In the reference section, I have included the citation for each editor's opening editorial. In the remainder of this section, I provide brief biographical sketches of each of the editors.

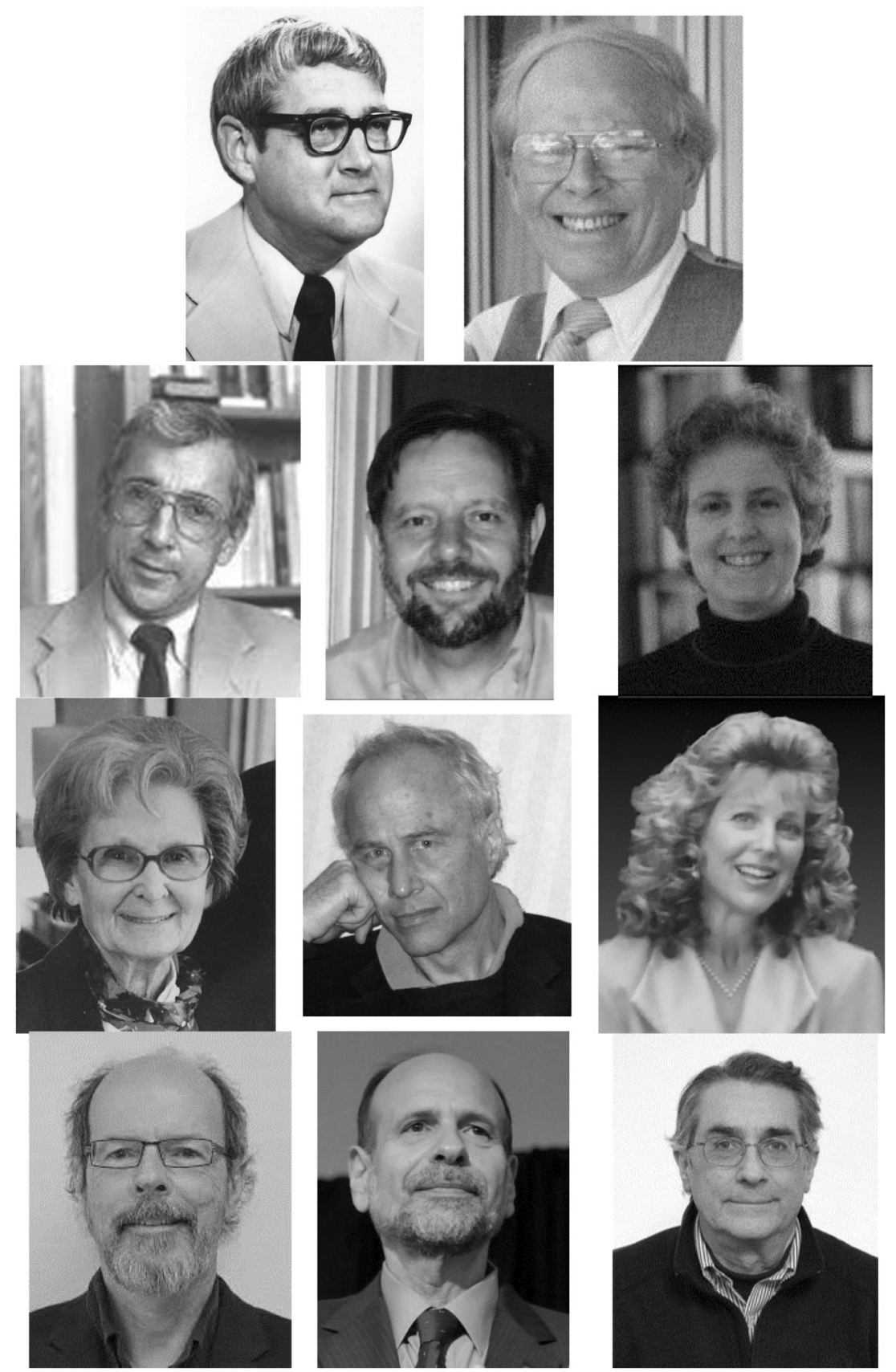

Fig. 2 The editors of Memory \& Cognition, 1973-2012 (left to right, top to bottom, in order of editorial term). Where possible, these are photos taken around the time of their editorial term 


\section{George E. Briggs (1973-1974)}

Briggs was born in Columbus, Ohio on May 27, 1926. He completed his undergraduate degree at Ohio State University in 1949, mentored by Arthur W. Melton; he completed his PhD at the University of Wisconsin in 1953, under the supervision of W. J. Brogden. Following a postdoc at Northwestern University with Benton J. Underwood, he took up a research associate position at Ohio State University with Paul Fitts; that position became a faculty position in 1958 . He moved to New Mexico State University as chair in 1973 . He died in Las Cruces, New Mexico, on December 10, 1974. Briggs is best known for his research in the realms of engineering psychology and human factors, and for his work on choice reaction time.

As coeditors, Brigg and Schulz wrote in their inaugural editorial (Briggs \& Schulz, 1973) that the new journal solicited integrative papers with theoretical advancement; they also counseled authors on the analysis and presentation of their data.

\section{Rudolph W. Schulz (1973-1976)}

Schulz was born on August 10, 1930, in Chicago, Illinois. He completed his undergraduate degree at Northwestern University in 1954 and then moved to Stanford University for his master's degree in 1955 before returning to Northwestern, where he completed his $\mathrm{PhD}$ in 1958, under the supervision of Benton J. Underwood. After a year at the Carnegie Institute of Technology, he became a faculty member at the University of Iowa in 1960, and spent his entire career there, including cycles serving as chair and as dean. He died May 31, 2015, in Iowa City, Iowa. Schulz is best known for his research in the realm of verbal learning and memory, especially in the domain of paired-associate learning.

\section{Robert G. Crowder (1977-1981)}

Crowder was born in Waterloo, Iowa, on September 16, 1939. He completed his undergraduate degree in 1960 and his $\mathrm{PhD}$ in 1965, both at the University of Michigan, where his supervisor was Arthur W. Melton. He moved immediately to a faculty position at Yale University, where he spent his entire career. His textbook, Principles of Learning and Memory (1976), is a classic in the field. He died July 27, 2000, in Hamden, Connecticut. Crowder is best known for his research on memory, particularly auditory memory, and for work on reading and on music cognition.

His editorial (Crowder, 1977) again emphasized the importance of integrated articles reporting programmatic research, but he also made room for single experiments, literature reviews, and other relevant work.

\section{Robert A. Bjork (1982-1985)}

Bjork was born in 1939, in Hector, Minnesota. He completed his undergraduate degree at the University of Minnesota in 1961; he completed his $\mathrm{PhD}$ at Stanford University in 1966, under the supervision of William K. Estes. After his first faculty position, at the University of Michigan, he moved to the University of California, Los Angeles. He also served as Editor of Psychological Review and as coeditor of Psychological Science in the Public Interest. Bjork is best known for his research on learning and memory, especially for his work on directed forgetting and on memory and metamemory considerations in optimizing instruction and self-regulated learning.

In his editorial (Bjork, 1982), after a year of handling manuscripts, Bjork wrote that he strongly endorsed Crowder's point about the relevance of single-experiment papers - that

Table 1. The editors of Memory \& Cognition from 1973 to 2012, with their terms

\begin{tabular}{llr}
\hline Editor & Affiliation & Term \\
\hline George E. Briggs* & Ohio State University/New Mexico State University & $1973-1974$ \\
Rudolph W. Schulz & University of Iowa & $1973-1976$ \\
Robert G. Crowder & Yale University & $1977-1981$ \\
Robert A. Bjork & University of California, Los Angeles & $1982-1985$ \\
Alice F. Healy & University of Colorado & $1986-1989$ \\
Margaret Jean Intons-Peterson & Indiana University & $1990-1993$ \\
Geoffrey R. Loftus & University of Washington & $1994-1997$ \\
Morton Ann Gernsbacher & University of Wisconsin-Madison \\
Colin M. MacLeod* & University of Toronto/University of Waterloo & $1998-2001$ \\
Brian H. Ross & University of Illinois & $2002-2005$ \\
James S. Nairne & Purdue University & $2006-2009$ \\
\hline
\end{tabular}

Note. The terms listed above represent the years in which each editor's name appeared on the cover of the journal; these are offset by 1 year from the actual appointment as editor, which began a year before the listed term. *Briggs and MacLeod each changed affiliations during their editorial terms 
number of experiments was often a poor measure of the value of a research contribution.

\section{Alice F. Healy (1986-1989)}

Healy (nee Fenvessy) was born in 1946, in Chicago, Illinois. She completed her undergraduate degree at Vassar College in 1968; she completed her PhD in 1973 at Rockefeller University, under the supervision of William K. Estes. After an initial faculty position at Yale University, she moved to the University of Colorado Boulder. Healy is best known for her research on memory and on training, and particularly for her work on short-term memory, long-term retention, reading, and psycholinguistic processes.

In her editorial (Healy, 1986), Healy commented on the high standards that the journal had developed, and renewed the points raised by her predecessors, including statistical advice. She also cautioned against comparisons across, rather than within, experiments.

\section{Margaret Jean Intons-Peterson (1990-1993)}

Intons-Peterson (nee Lowther) was born in Minneapolis, Minnesota, on October 3, 1930. She completed both her undergraduate degree (in 1951) and her PhD (in 1955) at the University of Minnesota, the latter after obtaining her master's degree from the University of Denver in 1953. Her PhD supervisor was Wallace A. Russell. From Minnesota, she moved to Indiana University, where she spent her entire academic career, including a cycle as chair. She was also editor of the Journal of Experimental Psychology: Human Perception and Performance. She died in Bloomington, Indiana, on August 24, 2019. Intons-Peterson is best known for her work on memory, especially on short-term memory and visual imagery; later in her career, she also studied gender and culture.

In her editorial (Intons-Peterson, 1990), she emphasized the importance of reviews that are "facilitative and educational." Intons-Peterson highlighted the kinds of substantial manuscripts and thorough statistics that Briggs and Schulz had encouraged. Intriguingly, she noted the important role of papers reporting failures to replicate.

\section{Geoffrey R. Loftus (1994-1997)}

Loftus was born in Syracuse, New York, in 1945. He completed his undergraduate degree at Brown University in 1967; he completed his $\mathrm{PhD}$ at Stanford University in 1971, under the supervision of Richard C. Atkinson. Following a postdoc at New York University with George Sperling, he took up a faculty position at the University of Washington, where he spent his entire career. Loftus is best known for his research on visual perception and on memory, including research on recognition memory and on factors affecting eyewitness testimony.

His editorial (Loftus, 1993) was the most comprehensive and directive to date. First, he echoed the value of single experiment papers. Second, he provided advice on preparation of papers; he also encouraged making archival data available. His third instruction was the most novel - that wherever possible, null hypothesis significance testing be replaced by presentation of data in figures, along with a strong suggestion about using confidence intervals.

\section{Morton Ann Gernsbacher (1998-2001)}

Gernsbacher was born in 1955, in Texas. She completed her undergraduate degree at the University of North Texas in 1976, her master's degree at the University of Texas at Dallas in 1980, supervised by James C. Bartlett, and her $\mathrm{PhD}$ at the University of Texas at Austin in 1983, supervised by Donald J. Foss. From Austin, she took up a faculty position at the University of Oregon, and from there moved to the University of Wisconsin-Madison. She also served as coeditor of Psychological Science in the Public Interest. Gernsbacher is best known for her research in the cognitive and neural mechanisms that underlie human communication.

Her editorial (Gernsbacher, 1998) encouraged authors to write more succinctly and to rule out alternative explanations with experiments, not "page after page of argumentative prose."

\section{Colin M. MacLeod (2002-2005)}

MacLeod was born in Montréal, Québec, Canada, in 1949. He completed his undergraduate degree at McGill University in 1971; he completed his $\mathrm{PhD}$ at the University of Washington in 1975, under the supervision of Thomas O. Nelson. Following a postdoc at Washington with Earl Hunt, he took up a faculty position at the University of Toronto at Scarborough, where he served as chair and as editor of the Canadian Journal of Experimental Psychology. In 2003, he moved to the University of Waterloo, where he again served as chair. MacLeod is best known for his research on memory and attention, particularly his work on interference in the Stroop effect, on implicit memory, and on the production effect in memory.

As the first non-American editor, his editorial (MacLeod, 2002) emphasized recruiting more international contributions from authors and reviewers, and he set out to increase international representation on the editorial board. He noted that articles had become shorter and promised to continue to emphasize concise presentation. 


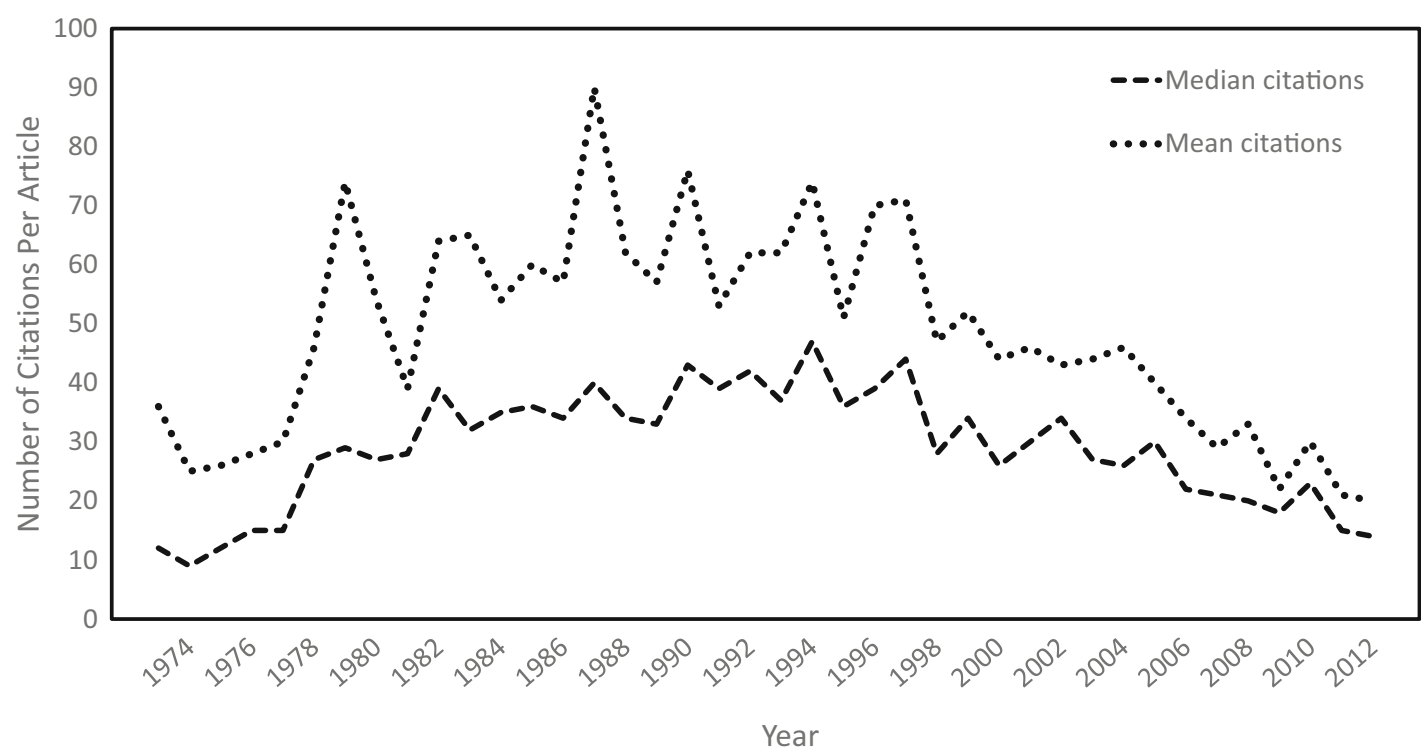

Fig. 3 Average (both median and mean) number of citations per article in a given year in Memory \& Cognition for each of the 40 years $1973-2012$

\section{Brian H. Ross (2006-2009)}

Ross was born in 1953 in New York City. He completed his undergraduate degree at Brown University in 1974, Master's degrees at Rutgers University (1977) and Yale University (1978), and his PhD at Stanford University in 1982, supervised by Gordon H. Bower. He then took up a faculty position at the University of Illinois for most of his career, including administrative positions as interim department head and acting dean. Ross retired from Illinois in 2016 to move to Minerva Schools at KGI, where he became dean of arts and sciences before retiring in 2020. He was long-time editor of the book series The Psychology of Learning and Motivation. Ross is best known for his research on problem-solving and learning in complex domains, categorization, and the use of concepts.

His editorial (Ross 2006) emphasized publishing "interesting, cutting-edge research," that did not have to be "perfect," and he also encouraged the archiving of data and materials given the growing possibilities for doing so.

\section{James S. Nairne (2010-2014)}

Nairne was born in 1954, in Pasadena, California. He completed his undergraduate degree at the University of California, Berkeley, in 1977, and completed his PhD at Yale University, in 1981, under the supervision of Robert G. Crowder. After taking up an initial faculty position at the University of Texas at Arlington, he moved to Purdue University. Nairne is best known for his research on memory, particularly his work on memory for order and on adaptive memory.

His editorial (Nairne, 2010) emphasized the importance of good data and of replication, and again called for concise articles: He placed a maximum of 8,000 words on all submissions (the current maximum is 8,500 ). To these, he added the importance of scholarship and of placing work in historical context. He also encouraged submission of research progress reports, which he characterized as "targeted assessments of mature phenomena."

\section{The influence of the journal and its editors}

From the first editorial, by Briggs and Schulz (1973), the remit of the journal has been made very clear - to "contain reports of the major investigative efforts of researchers concerned with the broad range of topics in human experimental psychology" (p. 1). One might reasonably ask whether there have been any trends in the content or domain of articles published over the 40 years. Sorting all 3,749 articles published in the 40 -year window seemed rather daunting. Consequently, in a very rough attempt to answer this question, I chose one issue per year (Issue Number 3 each year), and sorted the articles in that issue into a set of rather "ad hoc" categories (keeping the most highly cited article in the journal in mind). Based on this admittedly blunt instrument, the broad topics of the submissions remained fairly steady over the 40 years, but a few trends were apparent.

In the first 5-7 years, articles from two domains - social psychology and traditional learning - appeared in each issue, but they then disappeared, likely seeking more kindred speciality journals. Articles on attention were more prevalent in the earlier years, likely having declined as Attention, Perception, \& Psychophysics attracted more of that research. Articles on categorization did not appear until the early 1980s, but by 2012 formed a significant subset of the content. Articles on short- 
Table 2. The 40 most-cited articles in the first 40 years of Memory \& Cognition (1973-2012)

\begin{tabular}{|c|c|c|c|c|c|c|c|c|}
\hline $\begin{array}{l}\text { Rank by } \\
\text { total } \\
\text { citations }\end{array}$ & $\begin{array}{l}\text { Total } \\
\text { citations }\end{array}$ & $\begin{array}{l}\text { Rank by } \\
\text { mean } \\
\text { citations }\end{array}$ & $\begin{array}{l}\text { Mean } \\
\text { citations } \\
\text { (per Year) }\end{array}$ & Author(s) & Title & Year & $\begin{array}{l}\mathrm{Vol} / \\
\text { Issue }\end{array}$ & Pages \\
\hline 1 & 837 & 7 & 28.86 & Barsalou & Ad hoc categories. & 1983 & $11 / 3$ & $211-227$ \\
\hline 2 & 741 & 6 & 30.88 & Gardiner & Functional aspects of recollective experience. & 1988 & $16 / 4$ & $309-313$ \\
\hline 3 & 734 & 2 & 40.78 & $\begin{array}{l}\text { Maljkovic \& } \\
\text { Nakayama }\end{array}$ & Priming of popout: I. Role of features. & 1994 & $22 / 6$ & $657-672$ \\
\hline 4 & 642 & 5 & 33.79 & Rajaram & $\begin{array}{l}\text { Remembering and knowing: Two means of access to } \\
\text { the personal past. }\end{array}$ & 1993 & $21 / 1$ & $89-102$ \\
\hline 5 & 620 & 13 & 23.85 & Rayner \& Duffy & $\begin{array}{l}\text { Lexical complexity and fixation times in reading: } \\
\text { Effects of word frequency, verb complexity, and } \\
\text { lexical ambiguity. }\end{array}$ & 1986 & $14 / 3$ & 191-201 \\
\hline 6 & 599 & 12 & 23.96 & Van Orden & A rows is a rose: Spelling, sound, and reading. & 1987 & $15 / 3$ & $181-198$ \\
\hline 7 & 549 & 4 & 34.31 & Chalfonte \& Johnson & $\begin{array}{l}\text { Feature memory and binding in young and older } \\
\text { adults. }\end{array}$ & 1996 & $24 / 4$ & $403-416$ \\
\hline 8 & 500 & 14 & 22.73 & Nairne & A feature model of immediate memory. & 1990 & $18 / 3$ & $251-269$ \\
\hline 9 & 453 & 1 & 50.33 & Kensinger \& Corkin & $\begin{array}{l}\text { Memory enhancement for emotional words: Are } \\
\text { emotional words more vividly remembered than } \\
\text { neutral words? }\end{array}$ & 2003 & $31 / 8$ & $1169-1180$ \\
\hline 10 & 449 & 23 & 16.04 & $\begin{array}{l}\text { Seidenberg, Waters, } \\
\text { Sanders, \& Langer }\end{array}$ & $\begin{array}{l}\text { Pre- and postlexical loci of contextual effects on } \\
\text { word recognition. }\end{array}$ & 1984 & $12 / 4$ & $315-328$ \\
\hline 11 & 448 & 8 & 28.00 & Donaldson & $\begin{array}{l}\text { The role of decision processes in remembering and } \\
\text { knowing. }\end{array}$ & 1996 & $24 / 4$ & $523-533$ \\
\hline 12 & 441 & 19 & 17.64 & Holyoak \& Koh & $\begin{array}{l}\text { Surface and structural similarity in analogical } \\
\text { transfer. }\end{array}$ & 1987 & $15 / 4$ & $332-340$ \\
\hline 13 & 422 & 3 & 35.17 & Curran & Brain potentials of recollection and familiarity. & 2000 & $28 / 6$ & $923-938$ \\
\hline 13 & 422 & 36 & 10.82 & Dyer & $\begin{array}{l}\text { The Stroop phenomenon and its use in the study of } \\
\text { perceptual, cognitive, and response processes. }\end{array}$ & 1973 & $1 / 2$ & $106-120$ \\
\hline 15 & 420 & 28 & 13.12 & Becker & $\begin{array}{l}\text { Semantic context effects in visual word recognition: } \\
\text { An analysis of semantic strategies. }\end{array}$ & 1980 & $8 / 6$ & $493-512$ \\
\hline 16 & 414 & 21 & 16.56 & Roediger \& Blaxton & $\begin{array}{l}\text { Effects of varying modality, surface features, and } \\
\text { retention interval on priming in word-fragment } \\
\text { completion. }\end{array}$ & 1987 & $15 / 5$ & $379-388$ \\
\hline 17 & 408 & 9 & 27.20 & Tanaka \& Sengco & Features and their configuration in face recognition. & 1997 & $25 / 5$ & $583-592$ \\
\hline 18 & 390 & 33 & 11.82 & Logan \& Zbrodoff & $\begin{array}{l}\text { When it helps to be misled: Facilitative effects of } \\
\text { increasing the frequency of conflicting stimuli in a } \\
\text { Stroop-like task. }\end{array}$ & 1979 & $7 / 3$ & $166-174$ \\
\hline 19 & 385 & 10 & 25.67 & Norman \& Schacter & $\begin{array}{l}\text { False recognition in younger and older adults: } \\
\text { Exploring the characteristics of illusory memories. }\end{array}$ & 1997 & $25 / 6$ & $838-848$ \\
\hline 20 & 383 & 27 & 14.18 & Jolicoeur & The time to name disoriented natural objects. & 1985 & $13 / 4$ & 289-303 \\
\hline 21 & 378 & 35 & 11.12 & $\begin{array}{l}\text { Smith, Glenberg, \& } \\
\text { Bjork }\end{array}$ & Environmental context and human memory. & 1978 & $6 / 4$ & $342-353$ \\
\hline 22 & 374 & 20 & 17.00 & Van Petten \& Kutas & $\begin{array}{l}\text { Interactions between sentence context and word } \\
\text { frequency in event-related brain potentials. }\end{array}$ & 1990 & $18 / 4$ & $380-393$ \\
\hline 22 & 374 & 29 & 12.90 & $\begin{array}{l}\text { Evans, Barston, \& } \\
\quad \text { Pollard }\end{array}$ & $\begin{array}{l}\text { On the conflict between logic and belief in syllogistic } \\
\text { reasoning. }\end{array}$ & 1983 & $11 / 3$ & 295-306 \\
\hline 22 & 374 & 38 & 10.11 & Palmer & $\begin{array}{l}\text { The effects of contextual scenes on the identification } \\
\text { of objects. }\end{array}$ & 1975 & $3 / 5$ & $519-526$ \\
\hline 25 & 372 & 22 & 16.17 & Penney & $\begin{array}{l}\text { Modality effects and the structure of short-term ver- } \\
\text { bal memory. }\end{array}$ & 1989 & $17 / 4$ & $398-422$ \\
\hline 25 & 372 & 30 & 12.83 & Kutas \& Hillyard & $\begin{array}{l}\text { Event-related brain potentials to grammatical errors } \\
\text { and semantic anomalies. }\end{array}$ & 1983 & $11 / 5$ & $539-550$ \\
\hline 27 & 359 & 32 & 11.97 & Barsalou & $\begin{array}{l}\text { Context-independent and context-dependent infor- } \\
\text { mation in concepts. }\end{array}$ & 1982 & $10 / 1$ & $82-93$ \\
\hline 28 & 351 & 26 & 15.26 & Lindsay \& Johnson & $\begin{array}{l}\text { The eyewitness suggestibility effect and memory for } \\
\text { source. }\end{array}$ & 1989 & $17 / 3$ & $349-358$ \\
\hline 29 & 350 & 34 & 11.67 & Henik \& Tzelgov & $\begin{array}{l}\text { Is three greater than five: The relation between } \\
\text { physical and semantic size in comparison tasks. }\end{array}$ & 1982 & $10 / 4$ & 389-395 \\
\hline 30 & 345 & 39 & 9.58 & Neely & $\begin{array}{l}\text { Semantic priming and retrieval from lexical memory: } \\
\text { Evidence for facilitatory and inhibitory processes. }\end{array}$ & 1976 & $4 / 5$ & $648-654$ \\
\hline
\end{tabular}


Table 2. (continued)

\begin{tabular}{|c|c|c|c|c|c|c|c|c|}
\hline $\begin{array}{l}\text { Rank by } \\
\text { total } \\
\text { citations }\end{array}$ & $\begin{array}{l}\text { Total } \\
\text { citations }\end{array}$ & $\begin{array}{l}\text { Rank by } \\
\text { mean } \\
\text { citations }\end{array}$ & $\begin{array}{l}\text { Mean } \\
\text { citations } \\
\text { (per Year) }\end{array}$ & Author(s) & Title & Year & $\begin{array}{l}\text { Vol/ } \\
\text { Issue }\end{array}$ & Pages \\
\hline 31 & 342 & 17 & 21.38 & $\begin{array}{l}\text { Williams, Ellis, } \\
\text { Tyers, Healy, } \\
\text { Rose, \& Macleod }\end{array}$ & $\begin{array}{l}\text { The specificity of autobiographical memory and } \\
\text { imageability of the future. }\end{array}$ & 1996 & $24 / 1$ & $116-125$ \\
\hline 32 & 341 & 14 & 22.73 & $\begin{array}{l}\text { Herlitz, Nilsson, \& } \\
\text { Backman }\end{array}$ & Gender differences in episodic memory. & 1997 & $25 / 6$ & $801-811$ \\
\hline 32 & 341 & 24 & 15.50 & Rugg & $\begin{array}{l}\text { Event-related brain potentials dissociate repetition } \\
\text { effects of high- and low-frequency words. }\end{array}$ & 1990 & $18 / 4$ & $367-379$ \\
\hline 32 & 341 & 24 & 15.50 & Gardiner \& Java & $\begin{array}{l}\text { Recollective experience in word and nonword } \\
\text { recognition. }\end{array}$ & 1990 & $18 / 1$ & $23-30$ \\
\hline 35 & 336 & 31 & 12.44 & Hirtle\& Jonides & Evidence of hierarchies in cognitive maps. & 1985 & $13 / 3$ & $208-217$ \\
\hline 35 & 336 & 37 & 10.18 & Taft & $\begin{array}{l}\text { Recognition of affixed words and the word } \\
\text { frequency effect. }\end{array}$ & 1979 & $7 / 4$ & $263-272$ \\
\hline 37 & 335 & 40 & 9.05 & Paivio & Perceptual comparisons through the mind's eye. & 1975 & $3 / 6$ & $635-647$ \\
\hline 38 & 330 & 16 & 22.00 & Yonelinas & $\begin{array}{l}\text { Recognition memory ROCs for item and associative } \\
\text { information: The contribution of recollection and } \\
\text { familiarity. }\end{array}$ & 1997 & $25 / 6$ & $747-763$ \\
\hline 39 & 329 & 11 & 25.31 & $\begin{array}{l}\text { Stadler, Roediger, \& } \\
\quad \text { McDermott }\end{array}$ & Norms for word lists that create false memories. & 1999 & $27 / 3$ & $494-500$ \\
\hline 39 & 329 & 18 & 19.35 & Gathercole & $\begin{array}{l}\text { Is nonword repetition a test of phonological memory } \\
\text { or long-term knowledge? It all depends on the } \\
\text { nonwords. }\end{array}$ & 1995 & $23 / 1$ & $83-94$ \\
\hline
\end{tabular}

Note. The citation data were downloaded from Web of Science on March 25, 2020

term/working memory consistently formed a significant subset of the content. Also consistently in evidence were articles on reasoning and articles on imagery/spatial processing, although these were not as prevalent as working memory or categorization. By far, however, the predominant content area over the 40 years was long-term memory, broadly conceived. It would appear, then, as noted earlier, that the journal is aptly named.

The editors have influenced practice in experimental psychology, most notably in the reporting of data. This began with Briggs and Schulz (1973) emphasizing reporting not just central tendency but also variation. They required that all measures of central tendency "be accompanied by a suitable measure of variability" (and that mean square errors be reported with analysis of variance statistics). Healy (1986) reinforced this expectation in her editorial. Other data presentation recommendations have also influenced data reporting. Most directive in this regard was Loftus (1993), who strongly urged replacing null hypothesis significance testing (NHST) with the reporting of data in figures coupled with the use of confidence intervals. Both of these recommendations continue to be influential, although NHST is still prevalent. Loftus, and more recently Ross (2006), urged authors to archive their norms, stimuli, and data, consistent with progress throughout the discipline; this certainly is becoming standard operating procedure, in keeping with open science.

A "tension" has existed in editorials over the years with respect to the place of single-experiment versus multiple- experiment articles in the journal. Briggs and Schulz (1973) set the stage, stating that "it is expected that most research manuscripts will represent major data-collection efforts by the authors either through the report of a series of interrelated studies or through a single but comprehensive experimental design" (p. 1). Crowder (1977) tilted the balance heavily toward multiple-experiment articles, but left the door open for the "occasional" single-experiment article likely to "be of considerable impact." Bjork (1982) saw this trend as having gone too far, and argued for the value of single experiments (given sufficient power), a position that Healy (1986) echoed. IntonsPeterson (1990) reemphasized the importance of multipleexperiment articles; Loftus (1993) reemphasized the value of single-experiment articles. Throughout the 40 years, multipleexperiment articles have certainly dominated and it is now relatively rare to see a single-experiment article, in part perhaps because of other venues more suited to shorter articles.

Various editors have encouraged submissions other than theoretically oriented empirical articles; indeed, this has again been true since the launch of the journal. Briggs and Schulz (1973) solicited articles that represented theory development and those that constituted scholarly reviews, sentiments reflected in the editorials of Crowder (1977), Bjork (1982), and Intons-Peterson (1990). With the emergence in the stable of psychonomic journals of Psychonomic Bulletin \& Review, which specifically solicits review articles, these have become relatively uncommon in Memory \& Cognition, although 
Table 3. The most-cited article by year for the first 40 years of Memory \& Cognition (1973-2012)

\begin{tabular}{|c|c|c|c|c|c|}
\hline Year & Total Citations & Author(s) & Title & $\begin{array}{l}\text { Vol/ } \\
\text { Issue }\end{array}$ & Pages \\
\hline 1973 & 422 & Dyer & $\begin{array}{l}\text { The Stroop phenomenon and its use in the study of perceptual, } \\
\text { cognitive, and response processes. }\end{array}$ & $1 / 2$ & $106-120$ \\
\hline 1974 & 301 & Meyer, Schvaneveldt, \& Ruddy & $\begin{array}{l}\text { Functions of graphemic and phonemic codes in visual } \\
\text { word-recognition. }\end{array}$ & $2 / 2$ & $309-321$ \\
\hline 1975 & 374 & Palmer & The effects of contextual scenes on the identification of objects. & $3 / 5$ & $519-526$ \\
\hline 1976 & 345 & Neely & $\begin{array}{l}\text { Semantic priming and retrieval from lexical memory: Evidence } \\
\text { for facilitatory and inhibitory processes. }\end{array}$ & $4 / 5$ & $648-654$ \\
\hline 1977 & 206 & $\begin{array}{l}\text { Tweedy, Lapinski, } \\
\text { \& Schvaneveldt }\end{array}$ & $\begin{array}{l}\text { Semantic-context effects on word recognition: Influence of } \\
\text { varying the proportion of items presented in an appropriate } \\
\text { context. }\end{array}$ & $5 / 1$ & $84-89$ \\
\hline 1978 & 378 & Smith, Glenberg, \& Bjork & Environmental context and human memory. & $6 / 4$ & $342-353$ \\
\hline 1979 & 390 & Logan \& Zbrodoff & $\begin{array}{l}\text { When it helps to be misled: Facilitative effects of increasing the } \\
\text { frequency of conflicting stimuli in a Stroop-like task. }\end{array}$ & $7 / 3$ & $166-174$ \\
\hline 1980 & 420 & Becker & $\begin{array}{l}\text { Semantic context effects in visual word recognition: An analysis } \\
\text { of semantic strategies. }\end{array}$ & $8 / 6$ & $493-512$ \\
\hline 1981 & 316 & Onifer \& Swinney & $\begin{array}{l}\text { Accessing lexical ambiguities during sentence comprehension: } \\
\text { Effects of frequency of meaning and contextual bias. }\end{array}$ & $9 / 3$ & $225-236$ \\
\hline 1982 & 359 & Barsalou & $\begin{array}{l}\text { Context-independent and context-dependent information in } \\
\text { concepts. }\end{array}$ & $10 / 1$ & $82-93$ \\
\hline 1983 & 837 & Barsalou & Ad hoc categories. & $11 / 3$ & $211-227$ \\
\hline 1984 & 449 & $\begin{array}{l}\text { Seidenberg, Waters, Sanders, } \\
\text { \& Langer }\end{array}$ & $\begin{array}{l}\text { Pre- and postlexical loci of contextual effects on word } \\
\text { recognition. }\end{array}$ & $12 / 4$ & $315-328$ \\
\hline 1985 & 383 & Jolicoeur & The time to name disoriented natural objects. & $13 / 4$ & $289-303$ \\
\hline 1986 & 620 & Rayner \& Duffy & $\begin{array}{l}\text { Lexical complexity and fixation times in reading: Effects of } \\
\text { word frequency, verb complexity, and lexical ambiguity. }\end{array}$ & $14 / 3$ & $191-201$ \\
\hline 1987 & 599 & Van Orden & A rows is a rose: Spelling, sound, and reading. & $15 / 3$ & $181-198$ \\
\hline 1988 & 741 & Gardiner & Functional aspects of recollective experience. & $16 / 4$ & $309-313$ \\
\hline 1989 & 372 & Penney & Modality effects and the structure of short-term verbal memory. & $17 / 4$ & $398-422$ \\
\hline 1990 & 500 & Nairne & A feature model of immediate memory. & $18 / 3$ & $251-269$ \\
\hline 1991 & 220 & Van Petten \& Kutas & $\begin{array}{l}\text { Influence of semantic and syntactic context on open-class and } \\
\text { closed-class words. }\end{array}$ & $19 / 1$ & $95-112$ \\
\hline 1992 & 295 & Carrier \& Pashler & The influence of retrieval on retention. & $20 / 6$ & $633-642$ \\
\hline 1993 & 642 & Rajaram & $\begin{array}{l}\text { Remembering and knowing: Two means of access to the } \\
\text { personal past. }\end{array}$ & $21 / 1$ & 89-102 \\
\hline 1994 & 734 & Maljkovic \& Nakayama & Priming of popout: I. Role of features. & $22 / 6$ & $657-672$ \\
\hline 1995 & 329 & Gathercole & $\begin{array}{l}\text { Is nonword repetition a test of phonological memory or } \\
\text { long-term knowledge? It all depends on the nonwords. }\end{array}$ & $23 / 1$ & $83-94$ \\
\hline 1996 & 549 & Chalfonte \& Johnson & Feature memory and binding in young and older adults. & $24 / 4$ & $403-416$ \\
\hline 1997 & 408 & Tanaka \& Sengco & Features and their configuration in face recognition. & $25 / 5$ & $583-592$ \\
\hline 1998 & 235 & Rubin, Rahhal, \& Poon & Things learned in early adulthood are remembered best. & $26 / 1$ & $3-19$ \\
\hline 1999 & 329 & Stadler, Roediger, \& McDermott & Norms for word lists that create false memories. & $27 / 3$ & $494-500$ \\
\hline 2000 & 422 & Curran & Brain potentials of recollection and familiarity. & $28 / 6$ & $923-938$ \\
\hline 2001 & 252 & Cain, Oakhill, Barnes, \& Brant & $\begin{array}{l}\text { Comprehension skill, inference-making ability, and their } \\
\text { relation to knowledge. }\end{array}$ & $29 / 6$ & $850-859$ \\
\hline 2002 & 192 & Coulson \& Van Petten & $\begin{array}{l}\text { Conceptual integration and metaphor: An event-related } \\
\text { potential study. }\end{array}$ & $30 / 6$ & $958-968$ \\
\hline 2003 & 453 & Kensinger \& Corkin & $\begin{array}{l}\text { Memory enhancement for emotional words: Are emotional } \\
\text { words more vividly remembered than neutral words? }\end{array}$ & $31 / 8$ & $1169-1180$ \\
\hline 2004 & 287 & Berntsen \& Rubin & $\begin{array}{l}\text { Cultural life scripts structure recall from autobiographical } \\
\text { memory. }\end{array}$ & $32 / 3$ & $427-442$ \\
\hline 2005 & 255 & Henderson, Williams, \& Falk & Eye movements are functional during face learning. & $33 / 1$ & $98-106$ \\
\hline 2006 & 243 & Megreya \& Burton & Unfamiliar faces are not faces: Evidence from a matching task. & $34 / 4$ & $865-876$ \\
\hline 2007 & 210 & Christensen \& Schunn & $\begin{array}{l}\text { The relationship of analogical distance to analogical function } \\
\text { and preinventive structure: The case of engineering design. }\end{array}$ & $35 / 1$ & $29-38$ \\
\hline 2008 & 197 & $\begin{array}{l}\text { Smallwood, McSpadden, } \\
\quad \& \text { Schooler }\end{array}$ & $\begin{array}{l}\text { When attention matters: The curious incident of the } \\
\text { wandering mind. }\end{array}$ & $36 / 6$ & $1144-1150$ \\
\hline
\end{tabular}


Table 3. (continued)

\begin{tabular}{|c|c|c|c|c|c|}
\hline Year & Total Citations & Author(s) & Title & $\begin{array}{l}\text { Vol/ } \\
\text { Issue }\end{array}$ & Pages \\
\hline 2009 & 107 & $\begin{array}{l}\text { Fedorenko, Patel, Casasanto, } \\
\text { Winawer, \& Gibson }\end{array}$ & $\begin{array}{l}\text { Structural integration in language and music: Evidence for a } \\
\text { shared system. }\end{array}$ & $37 / 1$ & $1-9$ \\
\hline 2010 & 121 & Berntsen \& Rubin & $\begin{array}{l}\text { Remembering and forecasting: The relation between } \\
\text { autobiographical memory and episodic future thinking. }\end{array}$ & $38 / 3$ & $265-278$ \\
\hline 2011 & 324 & Toplak, West, \& Stanovich & $\begin{array}{l}\text { The Cognitive Reflection Test as a predictor of performance } \\
\text { on heuristics-and-biases tasks. }\end{array}$ & $39 / 7$ & $1275-1289$ \\
\hline 2012 & 123 & Storm \& Levy & $\begin{array}{l}\text { A progress report on the inhibitory account of retrieval-induced } \\
\text { forgetting. }\end{array}$ & $40 / 6$ & $827-843$ \\
\hline
\end{tabular}

Note. The citation data were downloaded from Web of Science on March 26, 2020

Nairne's (2010) call for research progress reports has led to a few such articles.

With the emphasis in recent years on the importance of replication in psychological research, it is interesting to note that this has long been emphasized in Memory \& Cognition. As noted earlier, Intons-Peterson (1990) encouraged submission of failures to replicate, although very few have in fact been published in the journal. Most recently, Nairne (2010) again highlighted the critical importance of replication. Within-article replication no doubt contributes to the predominance of multiple-experiment articles.

Then, there is the issue of the article's presentation. Multiple editors have encouraged clarity of writing, but Gernsbacher (1998) was the first to comment on the growing length of articles and to request more succinct reporting, which MacLeod (2002) confirmed had happened during Gernsbacher's term and would continue to be a goal. Nairne (2010) instituted an 8,000-word limit for articles in a further effort to rein in length (note, again, that that limit has since been reset to 8,500 words).

Finally, in his editorial, MacLeod (2002) sought to encourage more international participation in the journal at all levelseditorial board, authors, and reviewers. This certainly has happened: Considering only articles having at least one author from outside the U.S., MacLeod counted three countries and $13 \%$ of the articles in 1973, seven countries and $38 \%$ of the articles in 1987, and 15 countries and $41 \%$ of the articles in 2001. Extending to 2012, the 40th year, those numbers were 21 countries and $57 \%$ or the articles, demonstrating continuing growth in internationalization. At this writing, three of 11 associate editors and 24 of 51 consulting editors are based outside the U.S.

\section{The most influential articles}

As noted earlier, Memory \& Cognition has been successful from the outset in attracting submissions and in publishing high-quality articles in its domain. As evidence of its success, in 2018 (when last calculated), the journal had an impact factor of 1.95 and a 5-year impact factor of 2.520. Using the
Scimago Journal Rank (SJR) citation index, it is in Q1, reflecting the top $25 \%$ of journals in its subdiscipline. In short, the journal is highly respected.

Citation data were downloaded from the Web of Science database. Figure 3 shows the average number of citations per article published in the year indicated on the abscissa for each of the first 40 years. Both the medians and means are characterized by negative primacy and negative recency, with a long, steady asymptote. The 4-5-year negative primacy no doubt reflects the emergence of the journal on the scene, as it settled in and took its place among the top journals in cognitive psychology. The 8-10-year negative recency is no doubt simply a reflection of recent articles having not yet attracted the timedependent citations that they will accrue in the next few years. Possibly the best index of average citations for any given article, then, is obtained from the average of the asymptotic years (dropping 1973-1977 and 2005-2012). Taking the means of the annual means and medians, respectively, results in estimates of 58 and 34 citations per article over those 27 years. Of course, like any journal, many articles receive few citations, and relatively few articles are highly cited. It is those highly cited articles that are considered next.

Given the fact that this survey applies to the first 40 years of the journal, and with the pop music concept of the "Top 40" in mind, Table 2 presents the 40 most-cited articles over the target period. It is noteworthy that the top three most-cited articles reflect the range of the journal - from high-level cognition (Barsalou, 1983) through memory (Gardiner, 1988) to low-level cognition (Maljkovic \& Nakayama, 1994). Of the top 40 articles, the two domains most frequently included are memory and word recognition/reading, again reflecting the range of coverage of the journal. As is generally true in citations, three review articles and one set of norms also enjoy high citation rates. The names of four researchers each appear more than once in the top 40: Barsalou, Gardiner, Kutas, and Roediger.

In addition to ranking by total number of citations, and in an effort to "normalize for an article's age," Table 2 also presents total number of citations divided by number of years since publication, resulting in mean number of citations per 
year. This creates a somewhat different ranking of the mostcited articles, but the two measures of rank are moderately positively correlated, $r_{s}=.544$.

A second way to consider most-cited articles is to identify the most-cited article in each of the 40 years. This may be particularly informative in the more recent years, where articles can be expected to continue to attract citations. Table 3 therefore presents the top article in each of the 40 years. The two domains most frequently included remain memory and word recognition/reading. To the four researchers appearing more than once in Table 2 can be added three more: Berntsen, Rubin, and Schvaneveldt. Since 2004, no article in Table 3 has appeared in Table 2, indicative of the more recent articles not yet having had time to attract all of the citations that they will eventually attract. The article by Toplak, West, and Stanovich (2011) that reviews the Cognitive Reflection Test appears likely to become one of the highest-cited articles in the journal.

\section{Conclusion}

My goal in this article has been to survey the journal as it approaches its 50th year, examining its origin and progress, its editors, its influence, and its best known, most influential articles over its first 40 years. Like its sibling Psychonomic Society journals, Memory \& Cognition is a credit to the vision of the creators and subsequent leaders of the society. The journal quickly became a leading venue for the dissemination of ground breaking research in cognitive psychology, and remains so today. The upcoming decades hold great promise for exciting new research in the broad domain of cognition - research to be published in the pages of Memory \& Cognition.

Author note My research is supported by Discovery Grant A7459 from the Natural Sciences and Engineering Research Council (NSERC) of Canada. For their assistance in providing information about — and photographs of - the editors, I thank
James Craig, Henry Roediger, Kyle Schulz, Dominic Simon, Richard Shiffrin, Alison Yeung, and all of the former editors of the journal. I also thank Rob Sanford for providing the submission data, and Derek Besner, Myra Fernandes, Michael Masson, Evan Risko, Louis Shomette, and all of the former editors for comments on the initial draft. Correspondence may be sent to cmacleod@uwaterloo.ca

\section{References}

Bjork, R. A. (1982). Editorial: Some observations on a year's worth of manuscripts. Memory \& Cognition, 10, 1.

Briggs, G. E., \& Schulz, R. W. (1973). Editorial. Memory \& Cognition, 1, 1.

Crowder, R. G. (1977). Editor's comment. Memory \& Cognition, 5, 1.

Dewsbury, D. A. (1996). History of the Psychonomic Society II: The journal publishing program. Psychonomic Bulletin \& Review, 3, 322-338.

Dewsbury, D. A. (1997a). History of the Psychonomic Society III: The meetings of the Psychonomic Society. Psychonomic Bulletin \& Review, 4, 350-358.

Dewsbury, D. A. (1997b). History of the Psychonomic Society IV: The development of the Psychonomic Society. Psychonomic Bulletin \& Review, 4, 492-500.

Dewsbury, D. A., \& Bolles, R. C. (1995). The founding of the Psychonomic Society. Psychonomic Bulletin \& Review, 2, 216-233.

Dyer, F. N. (1973). The Stroop phenomenon and its use in the study of perceptual, cognitive, and response processes. Memory \& Cognition, 1, 106-120.

Gernsbacher, M. A. (1998). Editorial. Memory \& Cognition, $26,1$.

Healy, A. F. (1986). Editor's comments. Memory \& Cognition, 14, 1.

Intons-Peterson, M. J. (1990). Editorial. Memory \& Cognition, 18, 1-2.

Loftus, G. R. (1993). Editorial comment. Memory \& Cognition, 21, 1-3.

MacLeod, C. M. (2002). Editorial. Memory \& Cognition, 30, 1-2.

Nairne, J. S. (2010). Editorial. Memory \& Cognition, 38, 1-2.

Posner, M. I., Klein, R., Summers, J., \& Buggie, S. (1973). On the selection of signals. Memory \& Cognition, 1, 2-12.

Ross, B. H. (2006). Editorial. Memory \& Cognition, 34, 1-2.

Publisher's note Springer Nature remains neutral with regard to jurisdictional claims in published maps and institutional affiliations. 